\title{
Five new Brazilian species of the genus Trybliophorus (Orthoptera, Romaleidae)
}

\author{
Claudia M. A. Santos \& Cristiane V. Assis-Pujol
} Depto de Entomologia, Museu Nacional, Universidade Federal do Rio de Janeiro, Quinta da Boa Vista, São Cristóvão, 20940-040,
Rio de Janeiro, RJ, Brazil. (cmalves@mn.ufrj.br; cpujol @acd.ufrj.br)

\begin{abstract}
The new species Trybliophorus amazonicus, T. nigrus, T. rubricerus, T. olivaceus and T. paraensis from Amazonian region are described. Illustrations of male and female genitalia, as well as a map showing the geographical distribution of the species are included.
\end{abstract}

KEYWORDS. Neotropical, Romaleinae, Romaleini, systematics, Trybliophorus.

\section{INTRODUCTION}

The genus Trybliophorus Serville, 1831 is composed by species with long antennae, carinae of the head weakly marked, maxillary palps with the two terminal joints enlarged and the apical spoon shaped, front prominent, eyes globular and salient; pronotum with four transverse sulci, without lateral and principal carinae and with posterior margin triangular; tegmina never longer than abdomen and tarsi with last segment longer, surpassing the length of the others together (SERVILLE, 1831).

The genus was included in the subfamily Trybliophorinae by AmEDEGnato (1974). DesCAMPs (1978) transferred Trybliophorus modestus Bruner, 1920 to the genus Helicopacris Descamps, 1978, and the genus Trybliophorus was transferred to Romaleinae Amedegnato, 1974.

Seven species have been described for the genus: T. octomaculatus Serville, 1831, T. bivittatus Walker, 1870, T. corallipes (Gerstaecker, 1889), T. volucris (Gerstaecker, 1889), T. elegans Rehn, 1910, T. peruvianus Bruner, 1910 and T. sulcatus Descamps, 1981. The distribution of the genus includes Peru, Bolivia, Guyana and Brazil. Four species occur in Brazil: T. sulcatus, T. bivittatus, $T$. corallipes and T. volucris all of them in Pará and Amazonas. In this work five new species are described.

The material examined is deposited in the collection of Museu Nacional, Universidade Federal do Rio de Janeiro (MNRJ). For description of the external morphology it was used the terminology of SNODGRASS (1935) and OTTE (1981). The terminology of SLIFER (1939) was used for female genitalia and of DiRSH (1956) for male genitalia. The methodology of dissection of female genitalia was described by Assis-PuJol \& LECOQ (2000) and of male genitalia by DirSH (1956).

\section{Trybliophorus amazonicus sp. nov.} (Figs. 1-12, 61)

Etymology. From the State of Amazonas where the species occurs.

Types. Holotype or, BRAZIL, Amazonas: Tabatinga, XI.1978, C. S. Peixoto col. (MNRJ). Paratypes:
Tabatinga, 17 §,13 , XI.1978, C. S. Peixoto col.; 6 \%, 8 ;, VIII.1978, B. Silva col.;, X.1977, B. Silva col.;, XI.1977, B. Silva col.;, , XII.1977, L. G. Pereira col.; o, §, II.1978, L. G. Pereira col.; Benjamin Constant, \&, VIII.1977, B. Silva col. All in the MNRJ.

Diagnosis. Greenish or straw-colored band with brown margins from fastigium to tegmen, front strawcolored or greenish and antennae brown. Pronotum with two brown spots anterior to first sulcus and other two anterior to principal sulcus. Thorax laterally brown with green areas.

Description. General color of the body brown, dark brown, green, orange and straw-colored.

Male. Head in dorsal view with a straw-colored or greenish band extending from fastigium to occiput, widened caudad; fastigium long, lateral foveolae not visible from above (fig. 1). In lateral view, brown with subocular groove absent; eyes brown, globular and salient, more elevated than vertex (fig. 2); antennae filiform and brown, reaching seventh abdominal segment; maxillary palps straw-colored; in frontal view, strawcolored or greenish prolonged front (fig. 3).

Thorax, pronotum showing a pale band widened caudad with brown margins; two rounded areas brown anterior to first sulcus and other two anterior to principal sulcus; four transverse sulci well marked, first interrupted; prozona smaller than metazona (fig. 1); in lateral view (fig. 2) brown with green areas; meso and metapleura with episternum and epimerum light-brown and green; ventral greenish with intermesosternal space longer than wide and intermetasternal space open. Prosternal spine brownish and straw-colored.

Fore and middle legs straw-colored, slender and pilous; hind legs with orange and robust femora and straw-colored knees; carinulae and carinae weakly marked with denticulate projections; hind tibiae light-brown with inner portion orange, extremely pilous, smaller than femur, showing seven inner and seven outer black spines; hind tarsi straw-colored, long and very pilous, measuring together a half of tibia length; first joint twice as long as second, and third as long as the first and second together. Tegmen green with the costal area brown, as long as the abdomen. 

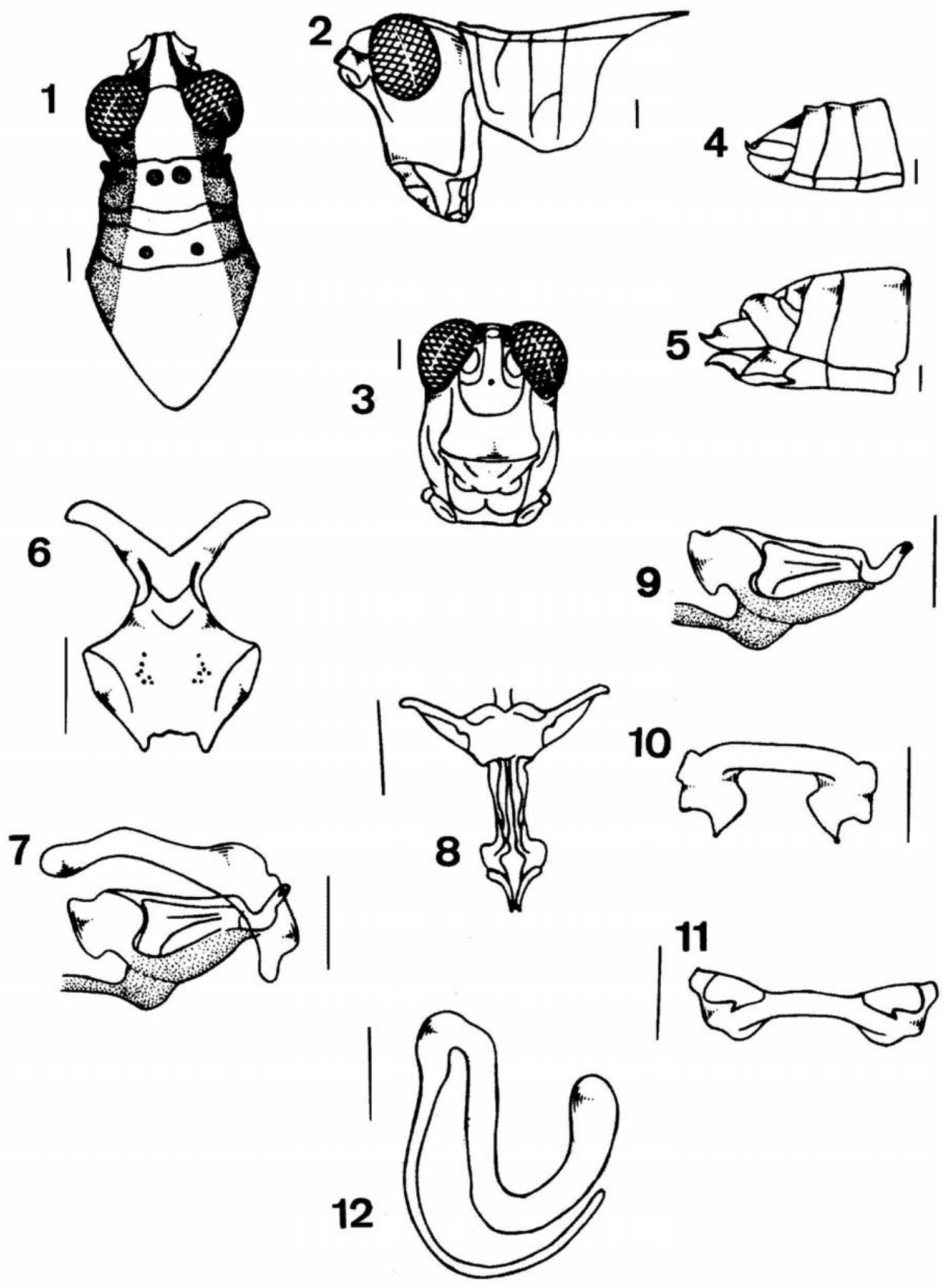

Figs. 1-12. Trybliophorus amazonicus sp. nov. Male: 1, head and pronotum, dorsal view; 2, lateral; 3, head, frontal; 4, distal abdominal segments, lateral; 5, female, distal abdominal segments, lateral; 6, cingulum, dorsal; 7, endophallus and cingulum, lateral; 8, endophallus, dorsal; 9, lateral; 10, epiphallus, dorsal; 11, frontal; 12, espermatheca. Scale lines: figs. 1-5, 1mm; 6-12, $0.5 \mathrm{~mm}$. 
Abdomen straw-colored. Some specimens with a brown band ventrally. Cerci parallel, long, with apex acute and curve, directed upwards (fig. 4).

Phallic complex. Apodems of cingulum with apex curve (figs. 6, 7), zigome V-shaped (fig. 6), endophallus with apical valves curved upwards (figs. 8, 9), epiphallus in dorsal view with bridge slightly curve and narrow, lophi with apex acute (fig. 10) and anchorae rounded (fig. 11).

Female. Differs from male by size of body, tegmen slightly smaller than abdomen and by yellowish maculation of genae not so clear in males. Valves of ovipositor with dorsal pair robust, smooth borders and acute apex; ventral pair with smooth borders and acute apex, curved downwards (fig. 5). Spermathecae with apical diverticulum absent represented only by a rounded knob, preapical diverticulum long, U-shaped and with end inflated (fig. 12).

Measurements in millimeters $\left(\sigma^{\prime}\right.$, $)$. Frontal costa to apex of tegmina, 25.5-27/34-35. Frontal costa to apex of abdomen, 26-27/33.5-38. Greatest diameter of eye, 2.5/3-3.3. Smallest diameter of eye, 2/ 2.3-2.6. Length of antenna, 18.5-21/21. Width of interocular space, 0.7-0.8/ 1-1.5. Width of head at eyes, 5-5.5/ 6. Width of head at genae, 4-4.5/ 5.3. Length of prozona, 3.5/4.54.8. Length of metazona, 4.7-5/ 6. Length of pronotum, 8.2-8.5/ 10.5-10.8. Maximum width of pronotum, 6-6.5/ 8. Length of head + pronotum, 12-12.5/16. Length of hind femur, 15/ 18-19. Maximum width of hind femur, 4/ 4.8-5. Length of tegmen, 16.7-17.6/21.5-22.

Distribution. Amazonas, Brazil (fig. 61).

\section{Trybliophorus nigrus sp. nov.}

(Figs. 13-24, 61)

Etymology. From nigrus (L) dark. Related to its dark coloration.

Types. Holotype $ð$, BRAZIL, Rondônia: Ouro Preto, VIII.1980, B. Silva col. (MNRJ). Paratypes: Rondônia: Porto Velho, 3 ơ, 5 क, XII.1978, B. Silva col; Ariquemes, 3 of, XI.1979, B. Silva col.; Cachoeira do Samuel, §, II.1978, B. Silva col.; Ouro Preto,, VIII.1983, B. Silva col., 25 ๙, 8 , VIII.1980, B. Silva col.; Amazonas: Jutaí BR 319, km 320, ६, IV.1979, B. Silva col. All in the MNRJ.

Diagnosis. Greenish or yellowish band with black margins from fastigium to tegmen, antennae black and pronotum with irregular black spots in prozona. Front, genae and lateral portions of thorax black with yellow maculation.

Description. General color of the body black, orange and olive green with smaller areas yellow, brown and red.

Male. Head in dorsal view with black elongated fastigium and foveolae not visible from above; a green or yellowish band from fastigium to occiput enlarged caudad (fig. 13). In lateral view, black with yellow maculation at genae; subocular groove absent; eyes brown, globular and salient, more elevated than vertex (fig. 14); antennae black and filiform, reaching seventh abdominal segment; maxillary palps with basal joints black and terminal yellow. In frontal view black with yellow maculations and front prolonged (fig. 15).

Thorax, pronotum showing a green or yellowish band widened caudad with irregular spots in prozona; four transverse sulci well marked, first interrupted; prozona smaller than metazona (fig. 13). In lateral view (fig. 14) black with yellowish areas; meso and metapleura with episternum and epimerum black with yellow spots. In ventral view black and yellow with intermesosternal space longer than wide and intermetasternal space open. Prosternal spine black and yellow.

Fore and middle legs black, slender and pilous, hind legs with orange robust femora and red knees; carinulae and carinae weakly marked with denticulate projections; hind tibiae orange in apical portion and black in basal portion, outer face completely black, extremely pilous, smaller than femur, with seven inner and seven outer black spines; hind tarsi black, long and very pilous, measuring together a half of tibia length; first joint twice as long as second, and third as long as first and second together. Tegmen as long as abdomen, olive green with costal area black.

Abdomen laterally brown and ventrally black. Cerci parallel with apex strongly acute, directed upwards (fig. 16).

Phallic complex. Apodems of cingulum long and lingulate (figs. 18, 19), zigome V-shaped (fig. 18), endophallus with apical valves short (fig. 20), slightly curved upwards (fig. 21), epiphallus in dorsal view with bridge slightly curve and short, lophi with apex rounded (fig. 22) and anchorae short and rounded (fig. 23).

Female. Differs from the male by size of body and by tegmen slightly smaller than abdomen. Valves of ovipositor with dorsal pair robust, smooth borders and acute apex, directed upwards and ventral pair smaller and directed downwards (fig. 17). Spermathecae with apical diverticulum absent represented only by a rounded knob, preapical diverticulum long, U-shaped, robust (fig. 24).

Remarks. Compared to T. amazonicus, T. nigrus has cerci with apex shorter and more curve; the valves of ovipositor less robust, with apex more rounded and spermathecae with preapical diverticulum shorter and more sinuous.

Measurements in millimeters $(\sigma, \varsubsetneqq)$. Frontal costa to apex of tegmina, 24-26/30.3-33. Frontal costa to apex of abdomen, 21.6-24/30.3-33. Greatest diameter of eye, 2.5$2.8 / 3$. Smallest diameter of eye, 1.8-2/2. Length of antenna, 20-21/22. Width of interocular space, 0.7-1/1. Width of head at eyes, $5 / 6$. Width of head at genae, $4 / 5$. Length of prozona, 3-3.2/ 4-4.5. Length of metazona, 4.5-4.6/ 6 . Length of pronotum, 7.5-7.8/10-10.5. Maximum width of pronotum, 5.8-6/ 7-7.5. Length of head + pronotum, 11.512/15-15.5. Length of hind femur, 14-15/ 17.5-19. Maximum width of hind femur, 4-4.5/ 5-5.5. Length of tegmen, 1617/20-21.

Distribution. Rondônia, Amazonas, Brazil (fig. 61).

Trybliophorus rubricerus sp. nov.

(Figs. 25-36, 61)

Etymology. From rubrum (L), red + keras (L), antennae. Related to the red antennae.

Types. Holotype ơ, BRAZIL, Amazonas: Jutaí, BR 319, km 369, IV.1979, B. Silva col. (MNRJ). Paratypes: Jutaí, BR 319, km 369, 2 \%, 3 q, IV.1979, B. Silva col. (MNRJ).

Diagnosis. Greenish or yellowish band, with black margins from fastigium to tegmen, antennae red and 

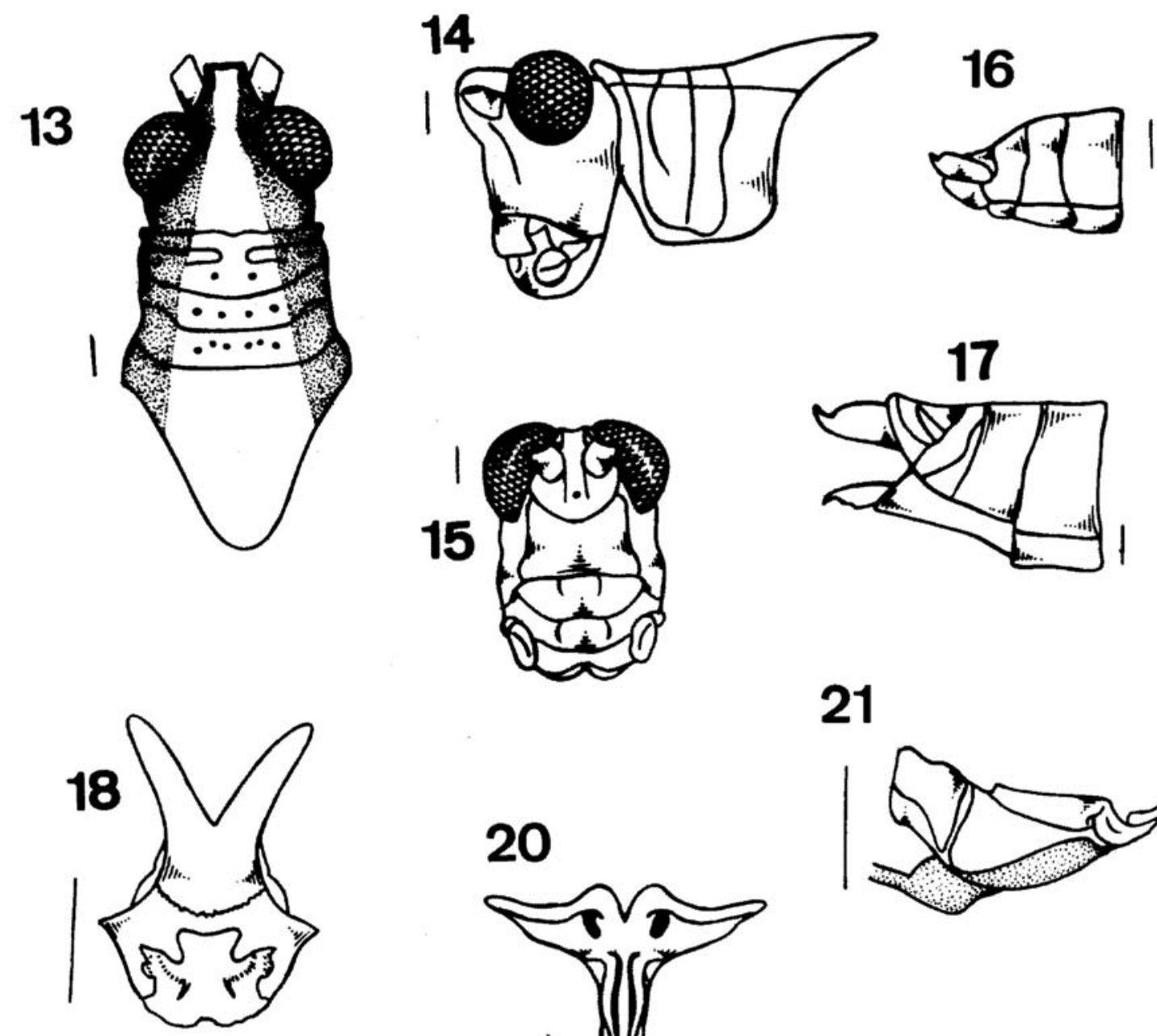

20

19
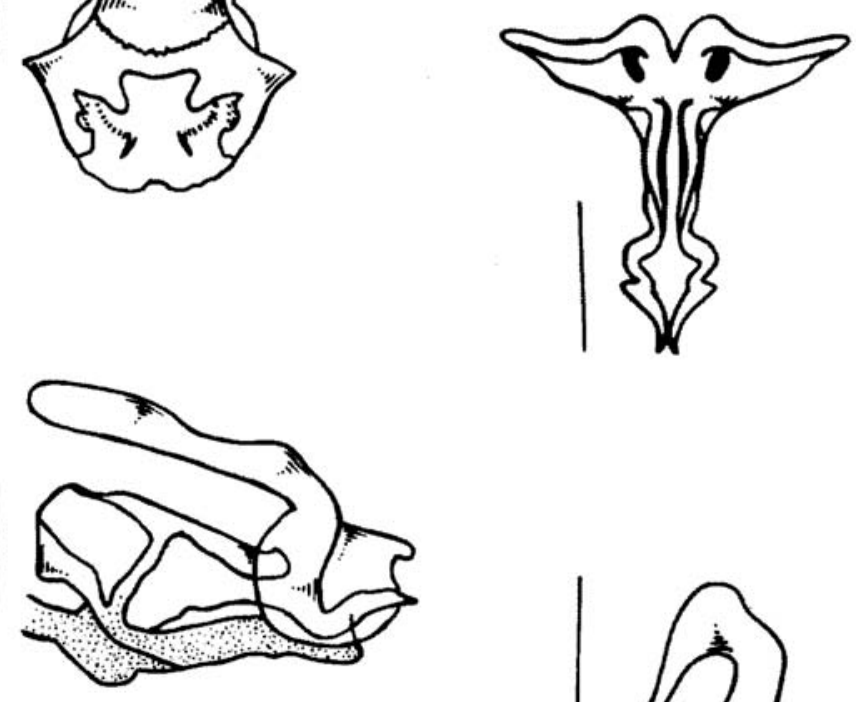

21

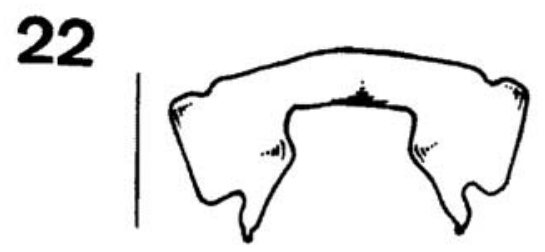

24
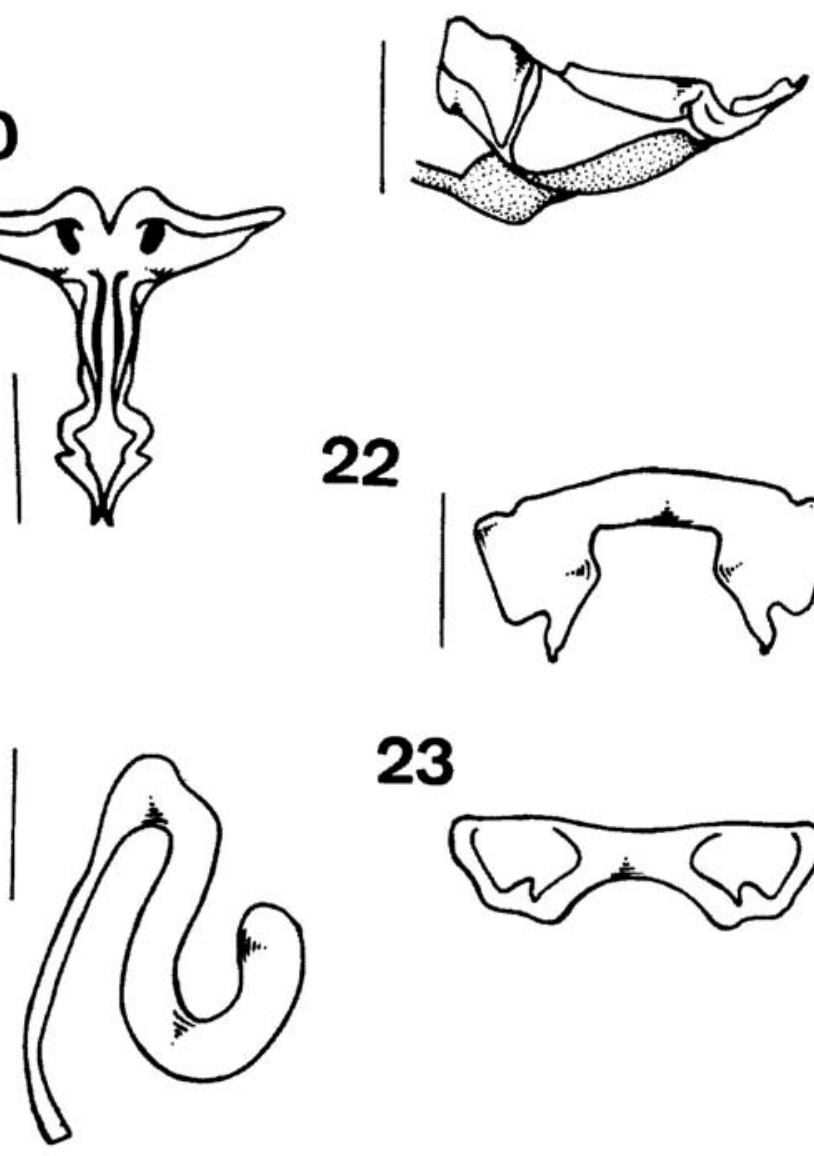

23

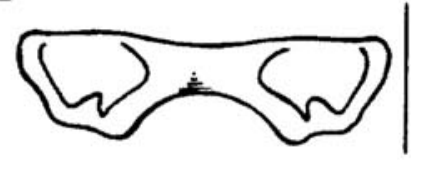

Figs. 13-24. Trybliophorus nigrus sp. nov. Male: 13, head and pronotum, dorsal view; 14, lateral; 15, head, frontal; 16, distal abdominal segments, lateral; 17, female, distal abdominal segments, lateral; 18, cingulum, dorsal; 19, endophallus and cingulum, lateral; 20, endophallus, dorsal; 21, lateral; 22, epiphallus, dorsal; 23, frontal; 24, espermatheca. Scale lines: figs. 13-17, 1mm; 18$24,0.5 \mathrm{~mm}$. 

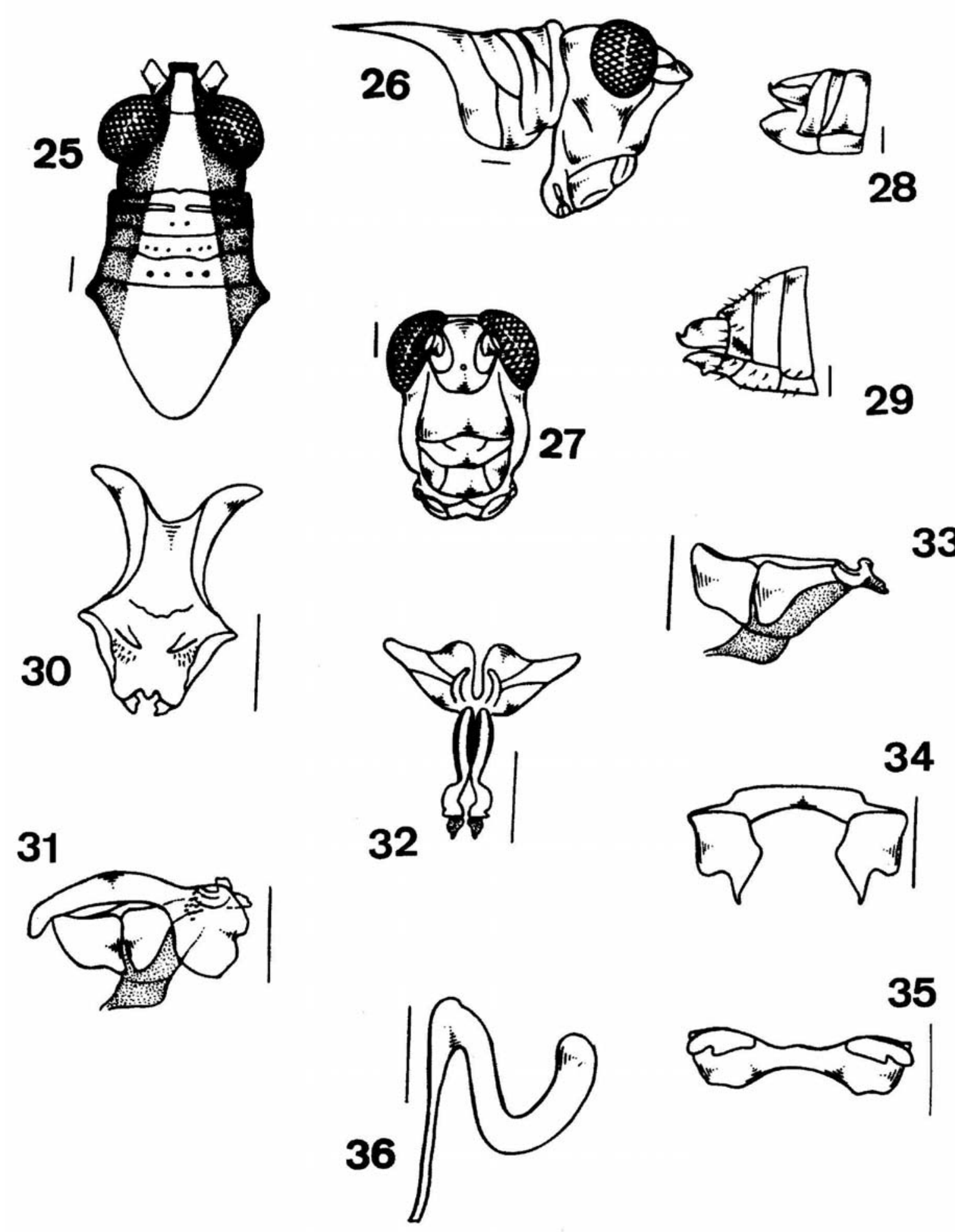

Figs. 25-36. Trybliophorus rubricerus sp. nov. Male: 25, head and pronotum, dorsal view; 26, lateral; 27, head, frontal; 28, distal abdominal segments, lateral; 29, female, distal abdominal segments, lateral; 30, cingulum, dorsal; 31, endophallus and cingulum, lateral; 32, endophallus, dorsal; 33, lateral; 34, epiphallus, dorsal; 35, frontal; 36, espermatheca. Scale lines: figs. 25-29, 1mm; 30-36, $0.5 \mathrm{~mm}$. 
pronotum with irregular black spots in prozona. Front, genae and lateral portions of thorax black with yellow maculations.

Description. General color of body black, orange and olive green with smaller areas yellow, brown and red.

Male. Head with dorsal view black elongated fastigium, foveolae not visible from above; a yellowish band extending from fastigium to occiput, enlarging caudad (fig. 25). In lateral view, black with yellow maculations at genae; subocular groove absent; eyes brown, globular and salient, more elevated than vertex (fig. 26); antennae filiform with scape and pedicel black and flagellum red, reaching seventh abdominal segment; maxillary palps with the basal joints black and terminal yellow. In frontal view, black with yellow maculations and front prolonged (fig. 27).

Thorax, pronotum showing a dorsal dark green or brownish band widened caudad, with irregular spots in prozona; four transverse sulci well marked, first interrupted; prozona smaller than metazona (fig. 25). In lateral view (fig. 26) black with yellowish areas, meso and metapleura showing episternum and epimerum black with yellow maculations. In ventral view black and yellow, with intermesosternal space longer than wide and intermetasternal space open. Prosternal spine black and yellow.

Fore and middle legs black, slender and pilous, hind legs with orange robust femora and orange knees; carinulae and carinae weakly marked with denticulate projections; hind tibiae orange in apical portion and black in basal portion, outer face completely black, extremely pilous, smaller than femur, with seven inner and seven outer black spines; hind tarsi orange, long and very pilous, measuring together a half of tibia length; first joint twice as long as second, and third as long as first and second together. Tegmen as long as the abdomen, varying from dark-green to brownish.

Abdomen laterally brown and ventrally black. Cerci narrow with apex short and curved upwards (fig. 28).

Phallic complex. Apodems of cingulum curved (figs. 30, 31), zigome U-shaped (fig. 30), endophallus with apical valves short (figs. 32, 33), epiphallus with short bridge, lophi with apex acute directed to each other (fig. 34) and anchorae short and rounded (fig. 35).

Female. Differs from male by size of body and tegmen slightly smaller than abdomen. Valves of ovipositor robust, very short (fig. 29). Spermathecae with apical diverticulum absent, represented only by a rounded knob, preapical diverticulum with end slightly inflate (fig. 36).

Remarks. Similar to T. nigrus, varying mainly in coloration and the pronotum that is a little more robust. Trybliophorus rubricerus has the femur less robust with denticulations of carinae less conspicuous than T. nigrus. Preapical diverticulum of spermathecae slightly more inflated than in T. nigrus and valves of ovipositor shorter than in others species here described.

Measurements in millimeters $(\sigma, \subsetneq)$. Frontal costa to apex of tegmina, 25/33. Frontal costa to apex of abdomen, 25/35. Greatest diameter of eye, 2.8/3. Smallest diameter of eye, 2/ 2.4. Length of antenna, 18/ 22. Width of interocular space, 1/ 1.2. Width of head at eyes, 5/ 6 . Width of head at genae, 4/ 5.5. Length of prozona, 3/ 4.
Length of metazona, 4/ 6. Length of pronotum, 7/ 10. Maximum width of pronotum, 5.4/ 7.5. Length of head + pronotum, 12/ 15. Length of hind femur, 14/ 18. Maximum width of hind femur, 3,5/ 5. Length of tegmen, 16/ 22.

Distribution. Amazonas, Brazil (fig. 61).

Trybliophorus olivaceus sp. nov. (Figs. 37-48, 61)

Etymology. From oliva (L), related to green coloration of tegmen.

Types. Holotype $₫$, BRAZIL, Amazonas: Benjamin Constant, VIII.1978, B. Silva col. (MNRJ). Paratypes: Benjamin Constant, ક, IX.1962, K. Lenko col.; ફ, IX.1977, I. C. Lima col.; 32 ॐ, 25 ‡, VIII.1978, B. Silva col.; Tefé, 3 ð’, †, IX .1981, O. Roppa \& P. Magno col.; ð, X.1979, B. Silva col.; Manaus, Igarapé Bolívia, §, VIII.1978, B. Silva col.; 2 †, V.1978, Roppa \& Silva col; Pará: Santarém, 2 đ', 2 †, X.1978, M. Cerdeira col. All in the MNRJ.

Diagnosis. Olive green band with red margins from fastigium to tegmen, antennae orange and pronotum with two red spots very close anterior to first sulcus and other two not so close in principal sulcus. Front, genae and thorax laterally reddish with green areas.

Description. General color of the body olive green, red and orange with small areas brown and straw-colored.

Male. Head, dorsal view elongated fastigium with sides red and median area green, foveolae not visible from above; a green band extending from fastigium to occiput, enlarging caudad (fig. 37). In lateral view two red areas interposed by a green band from fastigium to occiput, enlarged caudad; subocular groove absent; eyes brown, globular and salient, more elevated than vertex (fig. 38); antennae filiform with scape and pedicel straw-colored and flagellum orange, reaching seventh abdominal segment; maxillary palps straw-colored. In frontal view reddish with green maculation and front prolonged (fig. 39).

Thorax, pronotum showing a green band widened caudad; two reddish spots very close, anterior to first sulcus and other two not so close, in principal sulcus, four transverse sulci well marked, two first reddish and first interrupted; prozona smaller than metazona (fig. 37). In lateral view (fig. 38) reddish with green areas; mesopleura with episternum reddish and epimerum reddish and green and metapleura with episternum green and reddish and epimerum reddish. In ventral view green with intermesosternal space reddish, longer than wide and intermetasternal space open. Prosternal spine reddish and green.

Fore and middle legs straw-colored, slender and pilous; hind legs with robust and straw-colored femora; carinulae and carinae weakly marked with denticulate projections; knees robust, straw-colored and reddish; hind tibiae straw-colored with reddish portion, extremely pilous, smaller than the femur, with seven inner and seven outer black spines; hind tarsi straw-colored externally and reddish internally, long and very pilous, measuring together a half of tibia length; first joint twice as long as second and third as long as the first and the second together. Tegmen as long as the abdomen, olive green with the costal area reddish. 

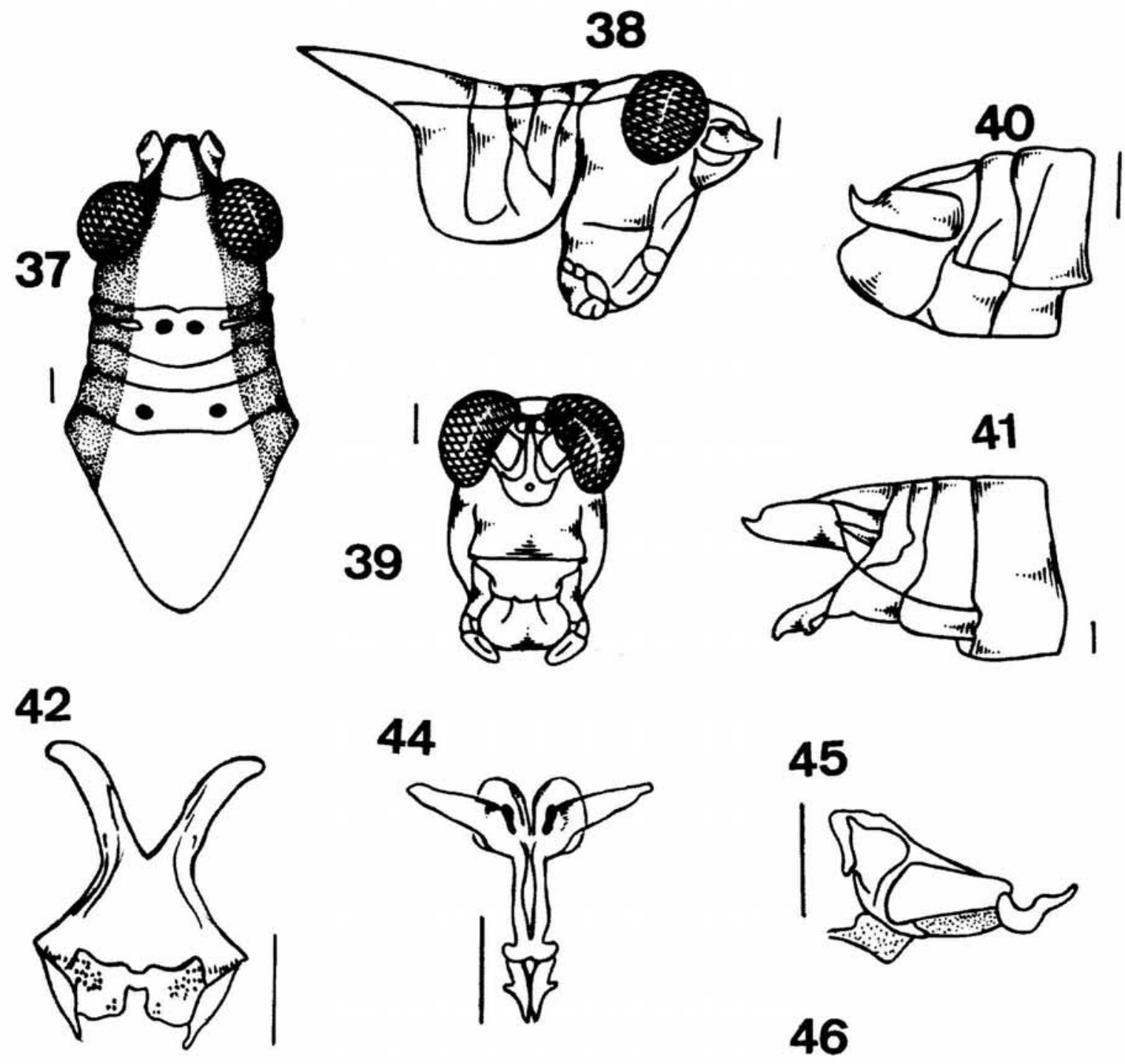

44
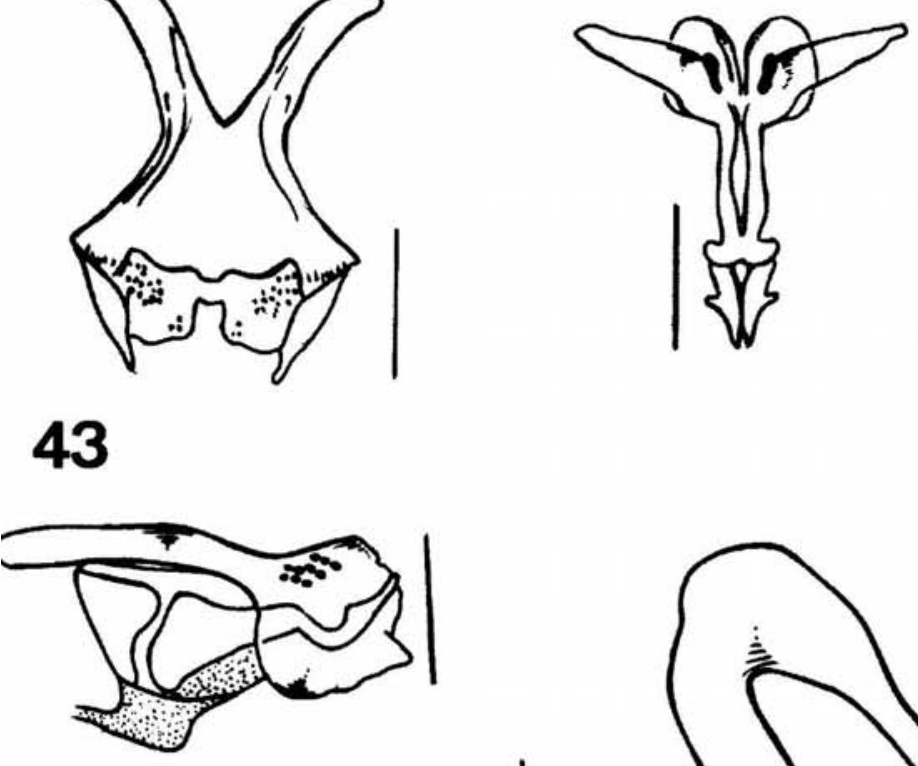

45

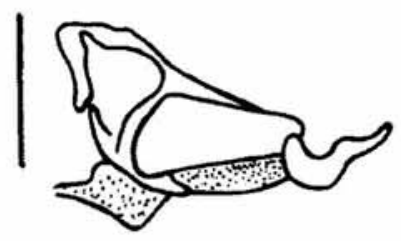

46

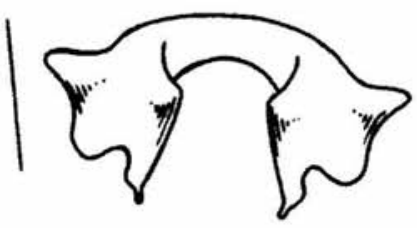

47
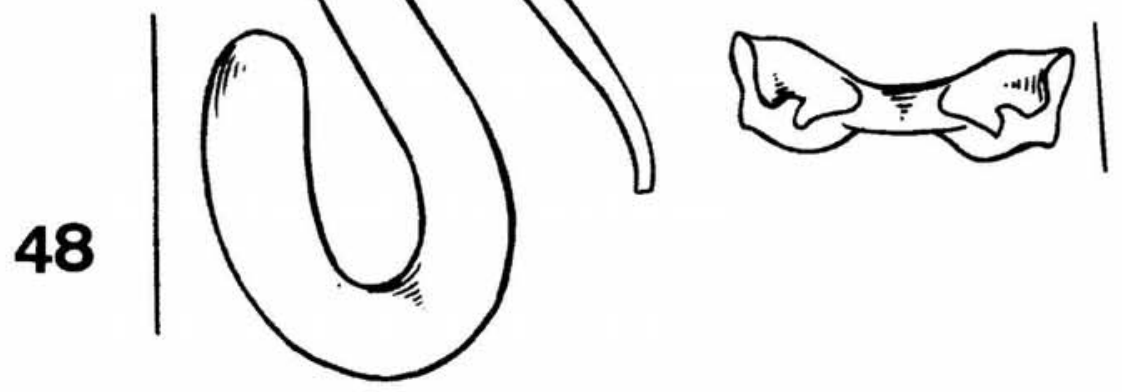

Figs. 37-48. Trybliophorus olivaceus sp. nov. Male: 37, head and pronotum, dorsal view; 38, lateral; 39, head, frontal; 40, distal abdominal segments, lateral; 41, female, distal abdominal segments, lateral; 42, cingulum, dorsal; 43, endophallus and cingulum, lateral; 44, endophallus, dorsal; 45, lateral; 46, epiphallus, dorsal; 47, frontal; 48, espermatheca. Scale lines: figs. 37-41, $1 \mathrm{~mm}$; $42-48,0.5 \mathrm{~mm}$. 
Abdomen green and reddish. Cerci long and parallel, with the apex acute and curve (fig. 40).

Phallic complex. Apodems of cingulum with the apex curved (figs. 42, 43), zigome V-shaped (fig. 42), endophallus with apical valves short directed upwards (figs. 44, 45), epiphallus in dorsal view with short and curved bridge, lophi with apex acute directed to each other (fig. 46) and anchorae short and rounded (fig. 47).

Female. Differs from male by size of body and by tegmen smaller than abdomen. Valves of ovipositor shorter and less robust than other species studied, with apex acute; ventral pair with borders smooth downward and apex rounded (fig. 41). Spermathecae with apical diverticulum absent, represented only by a rounded knob, preapical diverticulum robust, U-shaped, shorter and more sinuous than in other species (fig. 48).

Measurements in millimeters $(\sigma, q)$. Frontal costa to apex of tegmina, 27.5-28/34.2-37. Frontal costa to apex of abdomen, 27/34.5-43. Greatest diameter of eye, 2.6-3/ 1.93. Smallest diameter of eye, 1.9-2.2/ 1.3-2.2. Length of antenna, 21/21. Width of interocular space, 1/1-1.5. Width of head at eyes, 5.4-6/ 5.9-6. Width of head at genae, 44.4/ 5.5. Length of prozona, 3.7-4/ 4.5-4.9. Length of metazona, 5-6/ 6.3-7.1. Length of pronotum, 9-9.7/ 10.812. Maximum width of pronotum, 6/7-8. Length of head + pronotum, 13-14/ 15.9-18.5. Length of hind femur, 16/ 18.619. Maximum width of hind femur, 4.2/ 5-5.6. Length of tegmen, 17-18/22.

Distribution. Pará, Amazonas, Brazil (fig. 61).

\section{Trybliophorus paraensis sp. nov.}

(Figs. 49-60, 61) occurs.

Etymology. From the state of Pará where the species

Types. Holotype o, BRAZIL, Pará: Óbidos, IX.1978, D. L. Brito col. (MNRJ). Paratypes: Óbidos, 10 ఠ',

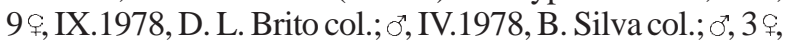
IX.1978, B. Silva col.; Amazonas: Tefé, 2 \%, IX.1981, O. Roppa \& P. Magno col. All in the MNRJ.

Diagnosis. Yellowish or greenish band with darkbrown margins from fastigium to pronotum, front brown, genae brownish with yellow maculations and antennae reddish. Tegmen green with dark-brown margins.

Description. General color of body olive green, orange and brown with small areas reddish, dark brown and yellowish.

Male. Head in dorsal view prolonged with fastigium slightly excavated and foveolae not visible from above; a yellowish band with dark brown borders extending from fastigium to occiput and widening caudad (fig. 49). Lateral view brownish with yellowish maculation at genae, subocular groove absent; eyes dark brown, globular and salient, more elevated than vertex (fig. 50); antennae filiform, scape and pedicel brown and flagellum reddish, reaching seventh abdominal segment; maxillary palps with basal joints brown and apical yellowish. Frontal view brown and front prolonged (fig. 51).

Thorax, pronotum with a green band widened caudad (weak in some specimens); four transverse sulci well marked; prozona smaller than metazona (fig. 49). In lateral view (fig. 50) brown; mesopleura with episternum brown and epimerum brown showing yellowish areas and metapleura with episternum brown showing yellowish areas and epimerum brown. In ventral view brown with the intermesosternal space longer than wider and intermetasternal space open. Prosternal spine brown.

Fore and middle legs brown, slender and pilous; hind legs with pale orange and robust femora, carinulae and carinae weakly marked with denticulate projections; knees paler in color; hind tibiae straw-colored, pilous, smaller than the femur, with seven inner and seven outer black spines; hind tarsi straw-colored, long and very pilous, measuring together a half of tibia length; the first joint is twice as long as the second, and third as long as first and second together. Tegmen as long as the abdomen, green in dorsal view with the costal area brown.

Abdomen brownish. Cerci parallel, long and narrow, with apex acute, slightly curved (fig. 52).

Phallic complex. Apodems of cingulum lingulate, short and slender (figs. 54, 55), zigome U-shaped (fig. 54), endophallus with apical valves short and straight and basal valves shorter than in the other species described (figs. 56, 57), epiphallus in dorsal view with bridge narrow and short, slightly curved, lophi with apex acute, directed inwards (fig. 58) and anchorae rounded and short (fig. 59).

Female. Differs from male by size of body and tegmen slightly smaller than abdomen. Valves of ovipositor with dorsal pair robust, smooth borders and acute apex; ventral pair with smooth borders and acute apex, curved downwards (fig. 53). Spermathecae with apical diverticulum absent represented only by a rounded knob, preapical diverticulum long, U-shaped and with lower edge curved (fig. 60).

Remarks. Trybliophorus paraensis has cerci narrower with apex less curved than in T. olivaceus. The endophallus has the basal valves shorter than in others species here described.

Measurements in millimeters $(\sigma, \subsetneq)$. Frontal costa to apex of tegmina, 23-25/ 31. Frontal costa to apex of abdomen, 22-24.5/ 32-36. Greatest diameter of eye, 2.32.5/3. Smallest diameter of eye, 1.7-2/ 2.3-2.4. Length of antenna, 19-21/ 20-20.5. Width of interocular space, $0.8 /$ 1-1.5. Width of head at eyes, 4.8-5/ 5.5-5.8. Width of head at genae, 3.8-4/ 5-5.2. Length of prozona, 3/ 4. Length of metazona, 4-4.4/ 5.2-5.5. Length of pronotum, 7-7.4/ 9.29.9. Maximum width of pronotum, 5.2-5.7/7-8. Length of head + pronotum, 11-11.9/14-14.8. Length of hind femur, 14-15/ 16-17. Maximum width of hind femur, 4/ 5-5.3. Length of tegmen, 14-15.5/ 19-20.8.

Distribution. Pará, Amazonas, Brazil (fig. 61).

Comments. All the species described are related to T. octomaculatus, T. corallipes and T. elegans. The characters considered to propose this relation were the size of the body, the measurements, and the yellow maculations on the face, pronotum and pleura. The species described differ mainly in the color pattern and in the phallic complex.

There is a remarkable convergence between some species of Trybliophorus and Saltonacris Descamps, 1976 (Proctolabinae), and it is probable that the species of the last genus mimesis some ones of Trybliophorus in the form of the body and coloration (DESCAMPS, 1977). 


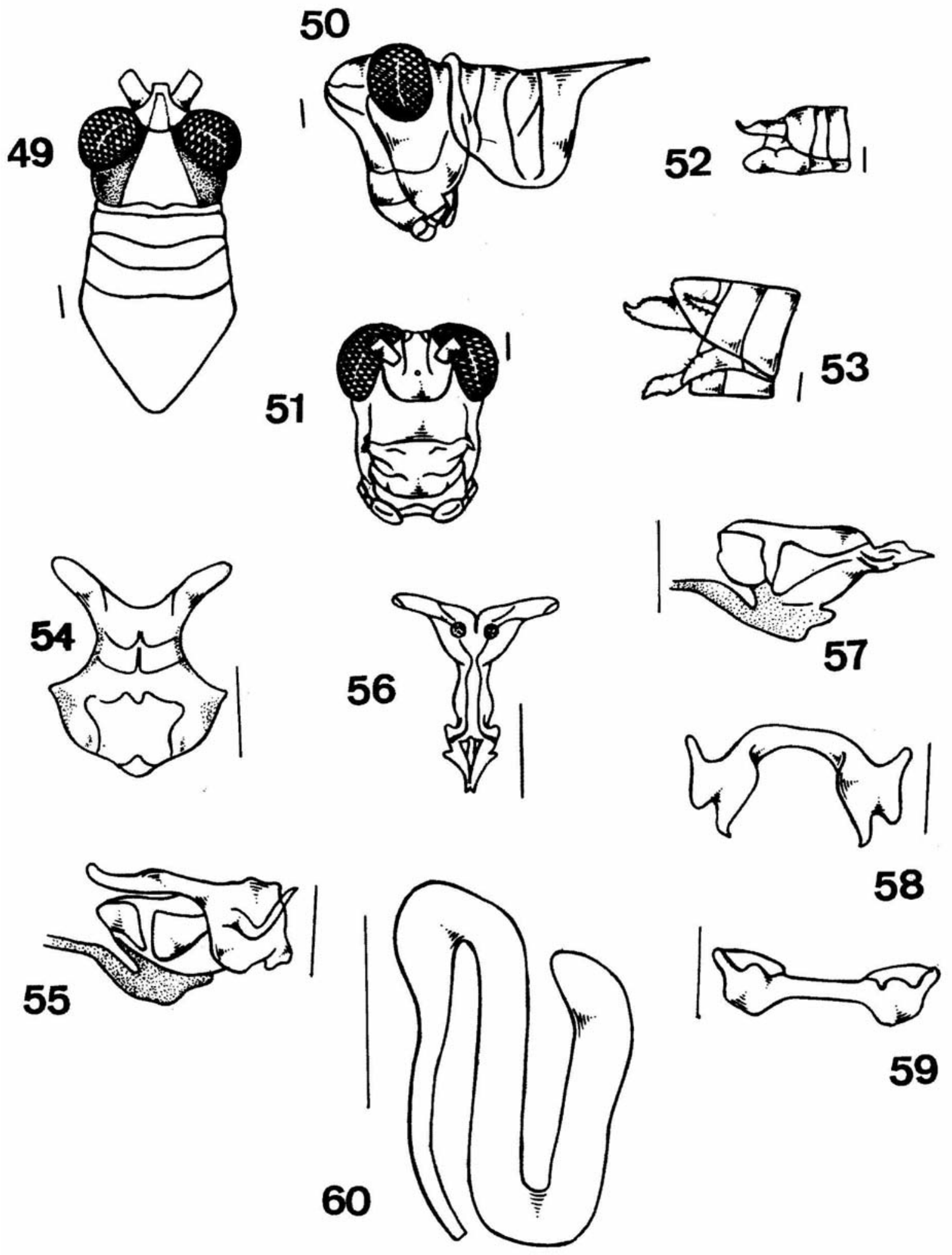

Figs. 49-60. Trybliophorus paraensis sp. nov. Male: 49, head and pronotum, dorsal view; 50, lateral; 51, head, frontal; 52, distal abdominal segments, lateral; 53, female, distal abdominal segments, lateral; 54, cingulum, dorsal; 55, endophallus and cingulum, lateral; 56, endophallus, dorsal; 57, lateral; 58, epiphallus, dorsal; 59, frontal; 60, espermatheca. Scale lines: figs. 49-53, 1mm; $54-60,0.5 \mathrm{~mm}$. 


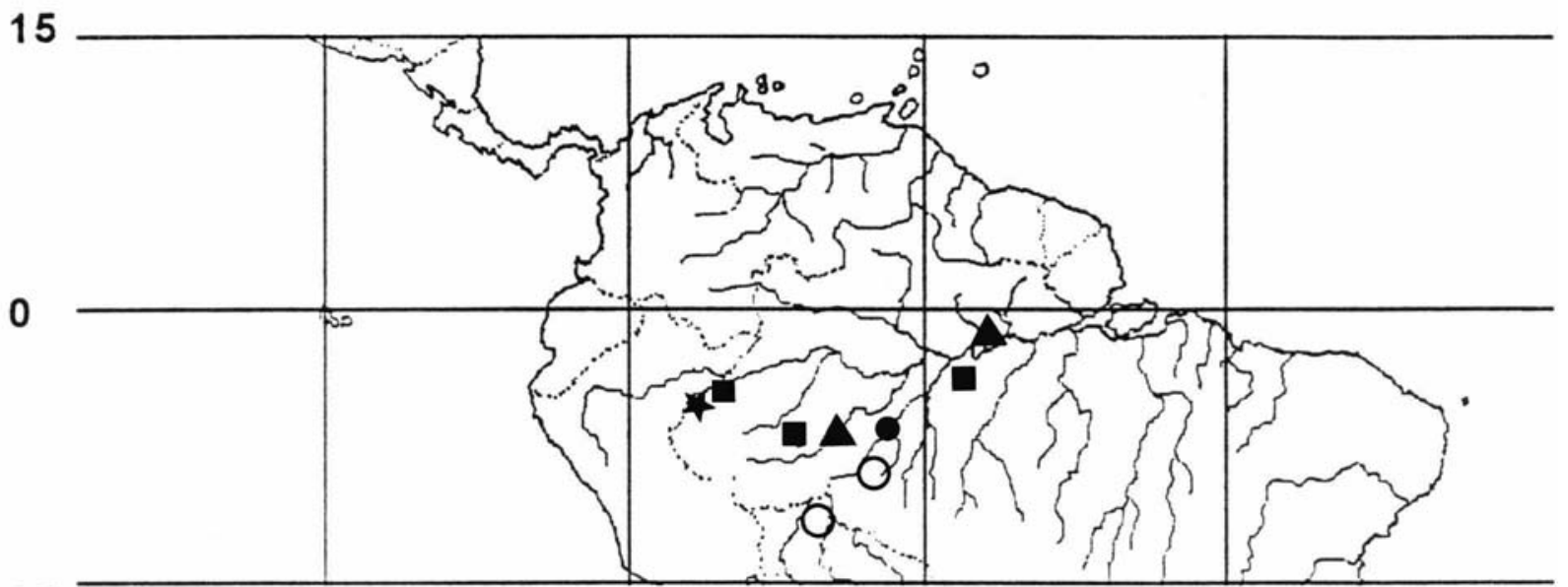

15

Fig. 61. Geographical distribution of the new Trybliophorus species ( $\downarrow$ T. amazonicus sp. nov.; $\bigcirc$ T. nigrus sp. nov.;



Acknowledgments. To Prof. Miguel Angel Monné Barrios (MNRJ) for the reading and suggestions, Luis Antonio A. Costa (MNRJ) for final art of illustrations. This work received support from CNPq proc. $\mathrm{n}^{\circ} 350057 / 2002-8$ and proc. $\mathrm{n}^{\circ} 131658 /$ 2002-6.

\section{REFERENCES}

Amedegnato, C. 1974. Les genres d'acridiens néotropicaux, leur classification par familles, sousfamilles et tribus. Acrida, Paris, 3:193-204.

Assis-Pujol, C. V. \& LecoQ, M. 2000. Comparative study of spermathecae in eleven Rhammatocerus (Saussure, 1861) grasshopper species (Orthoptera, Acrididae, Gomphocerinae, Scyllinini). Proceedings of the Entomological Society of Washington, Washington, 102(1):120-128.

Descamps, M. 1977. Étude des écossistèmes guyanais. I. Eumastacoidea \& Acridoidea dendrophiles (Orthoptera). Annales de la Société Entomologique de France, (N.S.), Paris, 13(2):193-236.
. 1978. La faune dendrophile neotropicale. II Revue de Taeneophorini et Ophthalmolampini (Orthoptera, Romaleidae). Bulletin du Museum National d'Histoire Naturelle, 3ème Ser., $\mathrm{n}^{\circ}$ 517, Zoologie, Paris, 355:371416.

Dirsh, V. M. 1956. The phallic complex in Acridoidea (Orthoptera) in relation to taxonomy. Transactions of the Royal Entomological Society of London, London, 108 (7):223-356.

Отте, D. 1981. The North American grasshoppers. Acrididae: Gomphocerinae and Acridinae. Cambridge, Harvard University. v. 1, 275p.

Serville, J. G. A. 1831. Revue methodique des insectes de l'ordre des Orthoptères. Annales des Sciences Naturelles, Paris, 22:262-292.

SLIfER, E. 1939. The internal genitalia of female Acridinae, Oedipodinae and Pauliniinae (Orthoptera, Acrididae). Journal of Morphology, Philadelphia, 65(3):437-469.

Snodgrass, R. E. 1935. Principles of insect morphology. New York, Mc Graw-Hill. 667p. 